\title{
Regional variations in risk factors for asthma in school children
}

\author{
Joshua A Lawson $\mathrm{MSc}^{1,2}$, Donna C Rennie $\mathrm{PhD}^{1,3}$, Ambikaipakan Senthilselvan $\mathrm{PhD}^{2}$, \\ Donald W Cockcroft MD ${ }^{4}$, Helen $\mathrm{H}_{\text {McDuffie }} \mathrm{PhD}^{1}$
}

\begin{abstract}
JA Lawson, DC Rennie, A Senthilselvan, DW Cockcroft, $\mathrm{HH}$ McDuffie. Regional variations in risk factors for asthma in school children. Can Respir J 2005;12(6):321-326.
\end{abstract}

BACKGROUND: The authors have previously reported an increased prevalence of asthma in Estevan, Saskatchewan (21.4\%) compared with Swift Current, Saskatchewan (16.2\%).

OBJECTIVE: To determine the association between asthma and personal and indoor environmental risk factors in these communities. METHODS: A population-based cross-sectional study was conducted in January 2000. A questionnaire was distributed to school children in grades 1 to 6 for completion by a parent. Multivariate logistic regression was used to examine associations between various risk factors and physician-diagnosed asthma.

RESULTS: Asthma was associated with respiratory allergy (adjusted OR $[$ adjOR] $=8.85,95 \%$ CI 6.79 to 11.54 ), early respiratory illness ( $\operatorname{adjOR}=2.81,95 \%$ CI 1.96 to 4.03$)$ and family history of asthma ( $\mathrm{adjOR}=2.37,95 \%$ CI 1.67 to 3.36). Several environmental factors varied with asthma by town. In Estevan, asthma was associated with home mould or dampness (adjOR $=1.82,95 \% \mathrm{CI} 1.23$ to 2.69 ) and was inversely associated with air conditioning ( $\mathrm{adjOR}=0.56,95 \% \mathrm{CI} 0.37$ to 0.85). The risk of asthma was increased if the child had previous exposure to environmental tobacco smoke from the mother in both communities (Swift Current: OR=1.87, 95\% CI 1.06 to 3.30; Estevan: $\mathrm{OR}=2.00,95 \% \mathrm{CI} 1.17$ to 3.43 ), and there was an inverse association with current exposure to environmental tobacco smoke from the mother in Estevan (OR=0.64, 95\% CI 0.40 to 1.00). When multivariate analyses were stratified by sex, the relationship between home mould or dampness and asthma was most prominent in girls in Estevan. CONCLUSIONS: Despite a similar regional location, different risk factors for asthma were identified in each community. Local environmental factors are important to consider when interpreting findings and planning asthma care.

Key Words: Asthma; Children; Environmental tobacco smoke; Geographical differences; Home mould or dampness; Risk factors

Athma is a multifactorial disease, which is known to be Aassociated with both personal and environmental factors. However, these relationships have been inconsistent among studies. Reasons behind these inconsistencies could be due to differences in study method, but could also be due to differences in local factors. Geographical variation in asthma prevalence has been reported both among $(1,2)$ and within countries $(3,4)$. Several studies $(4-9)$ have examined the risk factors for asthma in multiple communities, with overall associations being the major interest. Few studies $(5,6)$, however, have

\section{Les variations régionales des facteurs de risque d'asthme chez les enfants d'âge scolaire}

\begin{abstract}
HISTORIQUE : Les auteurs ont déjà rendu compte d'une prévalence d'asthme plus élevée à Estevan, en Saskatchewan (21,4 \%) qu'à Swift Current, en Saskatchewan (16,2 \%).

OBJECTIF : Déterminer l'association entre l'asthme et les facteurs de risque personnels et à l'intérieur du domicile au sein de ces collectivités.

MÉTHODOLOGIE : Une étude transversale en population générale a été menée en janvier 2000. Un questionnaire a été distribué à des enfants de $1^{\text {re }}$ à $6^{\mathrm{e}}$ année afin que leurs parents le remplissent. La régression logistique multivariée a été utilisée pour examiner les liens entre divers facteurs de risque et l'asthme diagnostiqué par un médecin.
\end{abstract}

RÉSULTATS : L'asthme était associé à des allergies respiratoires (RR rajusté $[R R R]=8,85,95 \%$ IC 6,79 à 11,54), à une maladie respiratoire précoce ( $R R R=2,81,95 \%$ IC 1,96 à 4,03) et à des antécédents familiaux d'asthme (RRR=2,37, 95 \% IC 1,67 à 3,36). Plusieurs facteurs environnementaux de l'asthme variaient selon la ville. À Estevan, l'asthme était relié à des moisissures ou à une humidité à domicile ( $R R R=1,82,95 \%$ IC 1,23 à 2,69) et était inversement proportionnel à la climatisation $(\mathrm{RRR}=0,56,95$ \% IC 0,37 à 0,85). Le risque d'asthme augmentait si l'enfant avait déjà été exposé à la fumée secondaire de la mère dans les deux collectivités (Swift Current : RR=1,87, $95 \%$ IC 1,06 à 3,30; Estevan : $\mathrm{RR}=2,00$; $95 \%$ IC 1,17 à 3,43) et il existait un lien inversement proportionnel avec l'exposition courante à la fumée secondaire de la mère à Estevan ( $\mathrm{RR}=0,64,95 \% \mathrm{IC} 0,40$ à 1,00). Lorsque les analyses multivariées étaient stratifiées selon le sexe, le lien entre les moisissures ou l'humidité à domicile et l'asthme dominait chez les fillettes d'Estevan. CONCLUSIONS : Malgré un lieu géographique similaire, différents facteurs de risque d'asthme ont été repérés dans chaque collectivité. Il est important de tenir compte des facteurs environnementaux locaux au moment d'interpréter les observations et de planifier les soins de l'asthme.

\footnotetext{
${ }^{1}$ Institute of Agricultural, Rural and Environmental Health, ${ }^{3}$ College of Nursing, ${ }^{4}$ Division of Respiratory Medicine, University of Saskatchewan, Saskatoon, Saskatchewan; ${ }^{2}$ Department of Public Health Sciences, University of Alberta, Edmonton, Alberta

Correspondence and reprints: Joshua Lawson, 3647 - 103 Hospital Drive, Institute of Agricultural, Rural and Environmental Health, Royal University Hospital, University of Saskatchewan, Saskatoon, Saskatchewan S7N OW8. Telephone 306-966-2978, fax 306-966-8799, e-mail lawson@sask.usask.ca
} 
TABLE 1

Distribution of personal characteristics in the towns of Swift Current and Estevan, Saskatchewan

\begin{tabular}{lccc}
\hline & $\begin{array}{c}\text { Swift Current } \\
(\mathbf{n = 1 0 7 7 )}(\%)\end{array}$ & $\begin{array}{c}\text { Estevan } \\
(\mathbf{n = 9 6 1 )}(\%)\end{array}$ & $\mathbf{P}$ \\
\hline Caucasian & 94.3 & 95.6 & 0.18 \\
Parents with >high school & 63.3 & 58.0 & 0.01 \\
$\quad$ education & & & \\
Living in a two-parent home & 84.3 & 88.0 & 0.02 \\
Report of a respiratory allergy & 27.6 & 27.5 & 0.96 \\
Report of an early & 11.8 & 9.6 & 0.11 \\
$\quad$ respiratory illness & 11.7 & & \\
Family history of asthma & 93.9 & 93.2 & 0.60 \\
Birthweight $\geq 2500 \mathrm{~g}$ & 16.7 & 16.8 & 0.98 \\
Born premature & 75.2 & 71.8 & 0.08 \\
Breastfed & $8.74 \pm 1.76$ & $8.68 \pm 1.78$ & 0.52 \\
Mean \pm SD age (years) & & &
\end{tabular}

prevalence than girls in Swift Current, and a similar prevalence to that of boys in Swift Current (10). These differences in asthma prevalence were not supported by differences in diagnostic labelling for asthma. The purpose of the current analysis was to investigate personal and indoor environmental characteristics in Swift Current and Estevan that may be associated with reported physician-diagnosed asthma in students in grades 1 to 6 , and to examine whether these associations are different by town.

\section{METHODS}

This was a cross-sectional population-based study of school children. The method of data collection has been previously described (10). Briefly, questionnaires were distributed to parents of all children attending grades 1 to 6 in Estevan and Swift Current schools. Pulmonary function testing was completed in children attending grades 1 to 4 and has been reported elsewhere (10). Ethical approval was obtained from the Advisory Committee on Ethics in Biomedical Research at the University of Saskatchewan, Saskatoon, Saskatchewan. Local school and health boards in each community also approved the study. The present analysis is based on questionnaire data only.

\section{Questionnaires}

A standardized method was used to collect data by questionnaire from both communities during the same time periods. In January 2000, questionnaires were distributed through the schools (10). Questions were derived from the American Thoracic Society's Children's Respiratory Disease Questionnaire (11) and the Canadian Student Lung Health Study (3).

The questionnaires sought information regarding demographics, respiratory health, general health, family history of asthma and indoor exposures. 'Asthma' was defined by a positive response to the question, "Has this child ever been diagnosed as having asthma by a doctor?". 'Respiratory allergy' was assessed by at least one positive response to the question, "Has this child ever had an allergy (hives, runny nose, swelling, itchiness and/or wheezing) to any of the following: house dust; grain dust; pollen; trees; grasses; mould or mildew; dog; cat; and/or birds/feathers?". The child's exposure to environmental tobacco smoke (ETS) was based on the mother's and father's smoking histories, and was categorized as never exposed (absence of smoking during the subject's life), previously exposed (had smoked, but quit smoking since the subject's birth) and currently exposed (currently smoking). The presence of mould or dampness in the home was assessed by a positive response to either the question, "Does your house have any damage caused by dampness (eg, wet spots on walls, floors)?", or the question, "Are there signs of mould or mildew in any living areas in your home?". Crowding was defined as the number of persons in the home divided by the number of rooms in the home. The proportion of life spent living in the current community was expressed as the number of years in the current location over age. Premature birth was defined as being born more than two weeks before the expected date. A history of early respiratory illness was considered to have occurred if there was a report of bronchitis, pneumonia, whooping cough or croup in the first two years of life. The type of dwelling was classified as single-family house or as other dwelling type, which included duplex, a more than two-family home and recreational vehicles, mobile homes and trailers.

\section{Statistical analysis}

All data were analyzed with the Statistical Package for the Social Sciences version 11.0 (SPSS Inc, USA). The prevalence of potential risk factors between the towns were compared using the $\chi^{2}$ test for proportions between categorical variables, and the independent samples $t$ test or Mann-Whitney test for continuous variables. Associations between asthma and various personal and indoor environmental characteristics were examined using a multivariate logistic regression model. Variables were included based on statistical significance, potential confounding and biological/clinical importance (12). The interaction between town and the other variables included in the main effects model was examined at the multivariate level. The OR and corresponding 95\% CI of the main effects were then adjusted based on the interaction effect (12). Goodness of fit was tested using the Hosmer-Lemeshow test (12). Finally, multivariate analyses were conducted separately for boys and girls.

\section{RESULTS}

Participation in both communities was excellent; $88.9 \%$ in Swift Current and $94.2 \%$ in Estevan. The sex distribution was similar between Swift Current and Estevan (49.9\% and $49.5 \%$ female, respectively). The prevalence of personal characteristics by town is presented in Table 1. A significantly higher proportion of children in Swift Current had a parent with more than a grade 12 education compared with children in Estevan, and a significantly lower proportion of children in Swift Current came from homes with two parents.

A significantly higher proportion of children in Estevan compared with Swift Current reported the presence of home mould or dampness, an air conditioner in the home, a dehumidifier in the home and gas heating (Table 2). A significantly lower proportion of children in Estevan reported the presence of a humidifier compared with Swift Current. The level of crowding and mean percentage of lifetime spent living in their present community was significantly greater in Estevan than in Swift Current.

\section{Unadjusted analysis}

The prevalence of asthma was significantly higher in Estevan compared with Swift Current (21.4\% versus $16.2 \%$, respectively, crude $\mathrm{OR}=1.41,95 \% \mathrm{CI} 1.13$ to 1.76 ). When considering personal characteristics, there were significant associations between asthma and respiratory allergy, early respiratory illness and family history of asthma (Table 3). Indoor characteristics associated with asthma were previous exposure to ETS from the mother, home mould or dampness, and living in a dwelling other than a single-family house (Table 4). 
TABLE 2

Distribution of indoor environmental characteristics in the towns of Swift Current and Estevan, Saskatchewan

\begin{tabular}{|c|c|c|c|}
\hline & $\begin{array}{c}\text { Swift Current } \\
(n=1077)(\%)\end{array}$ & $\begin{array}{c}\text { Estevan } \\
(n=961)(\%)\end{array}$ & $\mathbf{P}$ \\
\hline \multicolumn{4}{|l|}{ ETS exposure from the mother } \\
\hline Never & 59.8 & 58.7 & \\
\hline Previous & 10.8 & 12.1 & \\
\hline Current & 29.4 & 29.2 & 0.65 \\
\hline \multicolumn{4}{|l|}{ ETS exposure from the father } \\
\hline Never & 57.6 & 52.2 & \\
\hline Previous & 11.1 & 13.0 & \\
\hline Current & 31.3 & 34.8 & 0.05 \\
\hline Urban residence & 94.4 & 95.0 & 0.56 \\
\hline $\begin{array}{l}\text { Presence of home } \\
\text { mould or dampness }\end{array}$ & 19.8 & 26.7 & $<0.001$ \\
\hline Ever owned a pet & 66.9 & 64.1 & 0.19 \\
\hline Presence of a home air conditioner & 48.4 & 76.1 & $<0.001$ \\
\hline Presence of a home air filter & 29.0 & 30.9 & 0.34 \\
\hline Presence of a home humidifier & 30.5 & 26.2 & 0.04 \\
\hline Presence of a home dehumidifier & 5.1 & 9.6 & $<0.001$ \\
\hline Presence of a home fireplace & 30.0 & 29.6 & 0.72 \\
\hline Gas heating & 86.8 & 91.2 & $<0.01$ \\
\hline Electrical heating & 8.0 & 7.7 & 0.81 \\
\hline Single-family house & 88.1 & 86.1 & 0.17 \\
\hline Mean \pm SD crowding & $0.65 \pm 0.27$ & $0.67 \pm 0.28$ & 0.05 \\
\hline Mean \pm SD $\%$ time spent in location & $0.79 \pm 0.32$ & $0.84 \pm 0.30$ & $<0.01$ \\
\hline
\end{tabular}

ETS Environmental tobacco smoke

When associations with asthma were examined in each town at the univariate level, associations similar to the overall findings for asthma were found for respiratory allergy, early respiratory illness, family history of asthma and previous exposure to ETS from the mother in both communities. However, the towns differed in certain exposures for asthma. In Swift Current, associations with asthma were found for those of a nonCaucasian ethnicity (OR=2.88, 95\% CI 1.03 to 8.05$)$ and gas heating in the home $(\mathrm{OR}=1.75,95 \% \mathrm{CI} 1.00$ to 3.07$)$. In Estevan, associations were found between asthma and prior exposure to ETS from the father $(\mathrm{OR}=1.67,95 \%$ CI 1.07 to $2.60)$, the presence of home mould or dampness $(\mathrm{OR}=1.96$, $95 \%$ CI 1.41 to 2.72 ), the presence of air conditioning $(\mathrm{OR}=0.57,95 \% \mathrm{CI} 0.41$ to 0.80$)$, and the presence of a fireplace (OR=0.69, 95\% CI 0.48 to 0.99 ).

\section{Multivariate analyses}

In addition to the variable indicating the two communities, other risk factors were included in a multivariate logistic regression (change in $-2 \log$ likelihood $=444.90$, degrees of freedom $=18$, $\mathrm{P}<0.001)$. The strongest risk factor for asthma was the reporting of a respiratory allergy $(\mathrm{OR}=8.85,95 \% \mathrm{CI} 6.79$ to 11.54$)$. A history of early respiratory illness $(\mathrm{OR}=2.81,95 \% \mathrm{CI} 1.96$ to 4.03$)$ and a family history of asthma (OR=2.37, 95\% CI 1.67 to 3.36$)$ were also associated with asthma.

A significant effect modification was present between town and some household characteristics (Figure 1). In Estevan, the presence of home mould or dampness was associated with an increased risk of asthma (OR=1.82, 95\% CI 1.23 to 2.69) and an inverse association with the presence of an air conditioner $(\mathrm{OR}=0.56,95 \% \mathrm{CI} 0.37$ to 0.85$)$. These associations were not significant in Swift Current. Although there was an increased
TABLE 3

Distribution of personal characteristics by asthma

\begin{tabular}{|c|c|c|c|}
\hline & $\begin{array}{c}\text { No asthma } \\
\text { (n=1657), } \\
\text { n (\%) }\end{array}$ & $\begin{array}{c}\text { Asthma } \\
(\mathrm{n}=381), \\
\mathrm{n}(\%)\end{array}$ & $\begin{array}{c}\text { OR } \\
(95 \% \mathrm{Cl})\end{array}$ \\
\hline \multicolumn{4}{|l|}{ Ethnic background } \\
\hline Non-Caucasian & $88(5.3)$ & $15(3.9)$ & \\
\hline Caucasian & $1569(94.7)$ & $366(96.1)$ & $1.37(0.78-2.39)$ \\
\hline \multicolumn{4}{|c|}{ Parents with $>$ high school education } \\
\hline No & $655(39.5)$ & $144(37.8)$ & \\
\hline Yes & $1002(60.5)$ & $237(62.2)$ & $1.08(0.86-1.35)$ \\
\hline \multicolumn{4}{|c|}{ Living in a two-parent home } \\
\hline No & $229(13.8)$ & $55(14.4)$ & \\
\hline Yes & $1428(86.2)$ & $326(85.6)$ & $0.95(0.69-1.31)$ \\
\hline \multicolumn{4}{|c|}{ Report of respiratory allergy } \\
\hline No & $1351(81.5)$ & $126(33.1)$ & \\
\hline Yes & $306(18.5)$ & $255(66.9)$ & $8.94(6.98-11.44)$ \\
\hline \multicolumn{4}{|c|}{ Report of early respiratory illness } \\
\hline No & $1522(91.9)$ & $297(78.0)$ & \\
\hline Yes & $135(8.1)$ & $84(22.0)$ & $3.19(2.36-4.30)$ \\
\hline \multicolumn{4}{|l|}{ Family history of asthma } \\
\hline No & $1512(91.2)$ & $294(77.2)$ & \\
\hline Yes & $145(8.8)$ & $87(22.8)$ & $3.09(2.30-4.14)$ \\
\hline \multicolumn{4}{|l|}{ Birthweight } \\
\hline$\geq 2500 \mathrm{~g}$ & $1552(93.7)$ & $355(93.2)$ & \\
\hline$<2500 \mathrm{~g}$ & $105(6.3)$ & $26(6.8)$ & $1.08(0.69-1.69)$ \\
\hline \multicolumn{4}{|l|}{ Born premature } \\
\hline No & $1388(83.8)$ & $309(81.1)$ & \\
\hline Yes & $269(16.2)$ & $72(18.9)$ & $1.20(0.90-1.60)$ \\
\hline \multicolumn{4}{|l|}{ Breastfed } \\
\hline No & $441(26.6)$ & $97(25.5)$ & \\
\hline Yes & $1216(73.4)$ & $284(74.5)$ & $1.06(0.82-1.37)$ \\
\hline Mean \pm SD age (years) & $8.7 \pm 1.8$ & $8.8 \pm 1.7$ & $1.02(0.96-1.08)$ \\
\hline
\end{tabular}

risk of asthma in both communities if the child had previous ETS exposure from the mother (Swift Current: $O R=1.87,95 \%$ CI 1.06 to 3.30; Estevan: $\mathrm{OR}=2.00,95 \%$ CI 1.17 to 3.43), there was an inverse association between asthma and current ETS exposure in Estevan that was borderline significant $(\mathrm{OR}=0.64$, $95 \%$ CI 0.40 to 1.00 ), and there was no significant association between asthma and mother's current smoking in Swift Current.

\section{Stratified analysis by sex}

The final multivariate model was fitted separately for boys and girls (Table 5). In both boys and girls, respiratory allergy, family history of asthma and early childhood respiratory illness were associated with asthma. The association between asthma and past ETS exposure from the mother was significant in boys. In girls, the association between rural living and asthma was significant. Also in girls, the association between asthma and home mould or dampness was significant between towns, with girls showing a significant increase in the risk of asthma with the report of home mould or dampness in Estevan but not Swift Current.

\section{DISCUSSION}

The results of our study confirm previously identified associations between personal characteristics and asthma, and also highlight the need to interpret associations between asthma and indoor environmental characteristics at a local level. In the present study, respiratory allergy was most strongly associated 
TABLE 4

Distribution of indoor environmental factors by asthma

\begin{tabular}{|c|c|c|c|}
\hline & $\begin{array}{c}\text { No asthma } \\
(\mathrm{n}=1657), \\
\mathrm{n}(\%)\end{array}$ & $\begin{array}{c}\text { Asthma } \\
(\mathrm{n}=381) \\
\mathrm{n}(\%)\end{array}$ & $\begin{array}{c}\text { OR } \\
(95 \% \mathrm{Cl})\end{array}$ \\
\hline \multicolumn{4}{|c|}{ ETS exposure from mother } \\
\hline Never & $997(60.2)$ & $211(55.4)$ & \\
\hline Previous & $166(10.0)$ & $66(17.3)$ & $1.87(1.36-2.59)$ \\
\hline Current & $494(29.8)$ & $104(27.3)$ & $1.00(0.77-1.29)$ \\
\hline \multicolumn{4}{|c|}{ ETS exposure from father } \\
\hline Never & $920(55.5)$ & $202(53.0)$ & \\
\hline Previous & $189(11.4)$ & $56(14.7)$ & $1.35(0.97-1.89)$ \\
\hline Current & $548(33.1)$ & $123(32.3)$ & $1.02(0.80-1.31)$ \\
\hline \multicolumn{4}{|l|}{ Residence } \\
\hline Urban & $1574(95.0)$ & $356(93.4)$ & \\
\hline Rural & $83(5.0)$ & $25(6.6)$ & $1.33(0.84-2.11)$ \\
\hline \multicolumn{4}{|c|}{ Presence of home mould or dampness } \\
\hline No & $1300(78.5)$ & $268(70.3)$ & \\
\hline Yes & $357(21.5)$ & $113(29.7)$ & $1.54(1.20-1.97)$ \\
\hline \multicolumn{4}{|l|}{ Ever owned a pet } \\
\hline No & $576(34.8)$ & $126(33.1)$ & \\
\hline Yes & $1081(65.2)$ & $255(66.9)$ & $1.08(0.85-1.37)$ \\
\hline \multicolumn{4}{|c|}{ Presence of a home air conditioner } \\
\hline No & $629(38.0)$ & $157(41.2)$ & \\
\hline Yes & $1028(62.0)$ & $224(58.8)$ & $0.87(0.70-1.10)$ \\
\hline \multicolumn{4}{|c|}{ Presence of a home air filter } \\
\hline No & $1169(70.5)$ & $260(68.2)$ & \\
\hline Yes & $488(29.5)$ & $121(31.8)$ & $1.12(0.88-1.42)$ \\
\hline \multicolumn{4}{|c|}{ Presence of a home humidifier } \\
\hline No & $1182(71.3)$ & $276(72.4)$ & \\
\hline Yes & $475(28.7)$ & $105(27.6)$ & $0.95(0.74-1.21)$ \\
\hline \multicolumn{4}{|c|}{ Presence of a home dehumidifier } \\
\hline No & 1539 (92.9) & $352(92.4)$ & \\
\hline Yes & $118(7.1)$ & $29(7.6)$ & $1.08(0.70-1.64)$ \\
\hline \multicolumn{4}{|c|}{ Presence of a home fireplace } \\
\hline No & $1145(69.1)$ & $283(74.3)$ & \\
\hline Yes & $512(30.9)$ & $98(25.7)$ & $0.77(0.60-1.00)$ \\
\hline \multicolumn{4}{|l|}{ Gas heating } \\
\hline No & $191(11.5)$ & $36(9.4)$ & \\
\hline Yes & $1466(88.5)$ & $345(90.6)$ & $1.25(0.86-1.82)$ \\
\hline \multicolumn{4}{|l|}{ Electrical heating } \\
\hline No & $1522(91.9)$ & $356(93.4)$ & \\
\hline Yes & $135(8.1)$ & $25(6.6)$ & $0.79(0.51-1.23)$ \\
\hline \multicolumn{4}{|l|}{ Type of dwelling } \\
\hline Single-family house & $1459(88.1)$ & $317(83.2)$ & \\
\hline Other dwelling type & $198(11.9)$ & $64(16.8)$ & $1.49(1.10-2.02)$ \\
\hline Mean \pm SD crowding & $0.66 \pm 0.28$ & $0.66 \pm 0.28$ & $0.94(0.63-1.42)$ \\
\hline $\begin{array}{c}\text { Mean } \pm \text { SD \% time } \\
\text { spent in location }\end{array}$ & $0.81 \pm 0.30$ & $0.82 \pm 0.30$ & $1.11(0.76-1.61)$ \\
\hline
\end{tabular}

ETS Environmental tobacco smoke

with asthma. Similarly, strong associations between allergy and asthma have been seen in other studies $(13,14)$. Our study also supports previous studies $(5,15-19)$ showing that having at least one parent with asthma increases a child's risk of developing asthma. Whereas other studies report inconsistent associations between early respiratory illnesses and asthma, our findings of an association were consistent between communities.

We found that despite being in a similar geographical setting, the two study communities differed in their association between environmental characteristics and asthma. Although there was an increased risk of asthma associated with previous

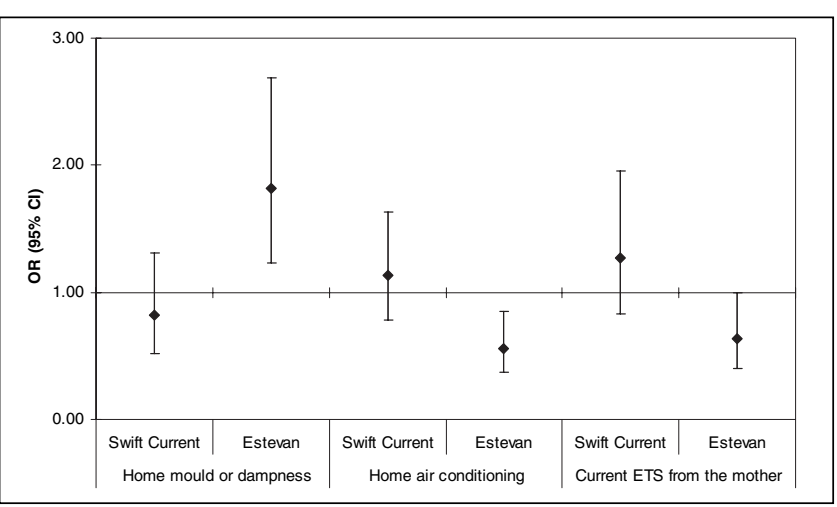

Figure 1) Adjusted ORs between asthma and home mould or dampness, home air conditioning and current exposure to environmental tobacco smoke (ETS) from the mother. ORs have been adjusted for town (Estevan or Swift Current, Saskatchewan), age, sex, respiratory allergy, early respiratory illness, family history of asthma, ETS exposure from the mother, ETS exposure from the father, urban residence, home mould or dampness, air conditioning, home type and interaction terms for town by home mould or dampness, town by air conditioning, town by ETS exposure from the mother and town by home type

ETS exposure from the mother in both communities, associations between current ETS exposure from the mother and asthma differed between communities, with no association in Swift Current and an inverse association in Estevan. Several studies and reviews $(8,14,20-25)$ have shown that parental smoking, especially maternal smoking, is associated with asthma or asthma symptoms. Our findings for current ETS exposure are difficult to interpret. It is possible that many of the mothers quit smoking as a result of their child's asthma diagnosis, or those who are currently smoking may be smoking outside of the child's environment, resulting in no relationship or inverse associations with asthma. More information about the nature of current smoking patterns of parents is required.

In Estevan, but not in Swift Current, the presence of home mould or dampness was associated with an increased risk of asthma. The strength of the association in Estevan was consistent with other studies involving children, which generally show positive associations with mould and/or dampness $(8,9,26,27)$, with ORs of approximately 2.00 (27). Differences in the results between previously conducted studies may be attributed to the differences in definitions and methods used to assess exposure to home mould or dampness. Home air conditioning in Estevan was inversely associated with asthma. Previous studies $(7,28,29)$ have shown conflicting results of associations between asthma symptoms and the use of air conditioners. The mechanisms relating use of air conditioners and asthma are not known. Because of the general problems with outdoor dust in Estevan, with agricultural practices and nearby strip coal mining, it is possible that air conditioners are used to control the quality of the indoor environment of homes. More specific information regarding the type, location, frequency of cleaning, or reasons for the use of air conditioners would assist in identifying reasons for this observed association.

In the sex-stratified analysis, similar associations between asthma and risk factors were similar for both boys and girls; however, levels of significance were not met for the associations between mould or dampness and asthma in boys, and for previous ETS exposure from the mother in girls. The lack of statistical 
TABLE 5

Multivariate logistic regression model of risk factors for asthma stratified by sex

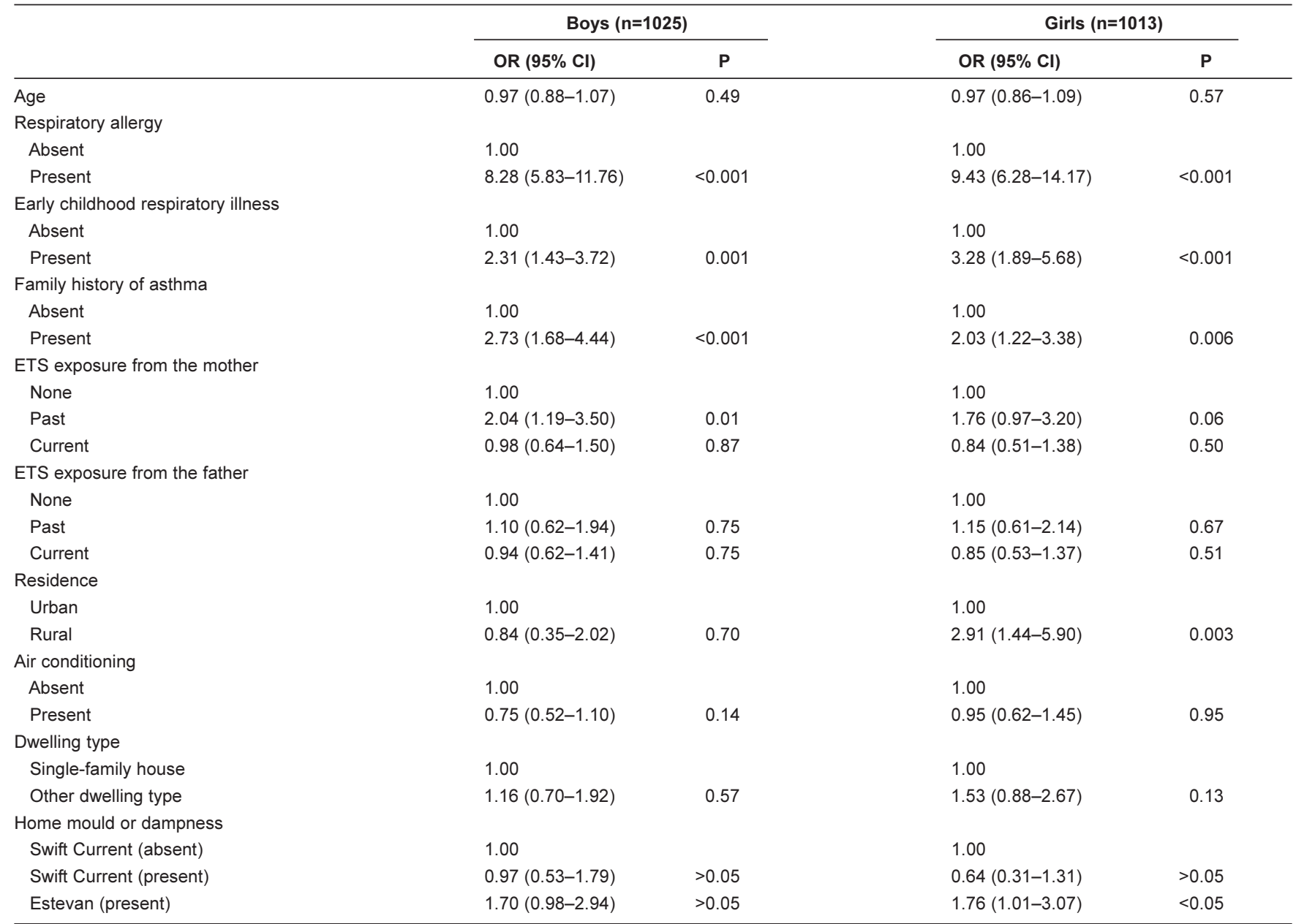

Adjusted for all of the variables in the model, town (Estevan or Swift Current, Saskatchewan) and interaction terms for home mould or dampness by town. ETS Environmental tobacco smoke

significance may be due to reduced sample size in the stratified analysis because the patterns and strength of associations were similar between boys and girls. A notable difference, however, was the significant association between rural living and asthma in girls. This finding for girls contradicts the more common pattern of reduced risk of asthma in rural settings such as farms (30). Reasons for this finding could not be determined from the present study. Future investigations should consider sex when investigating rural exposures.

Several studies (4-9) have investigated risk factors associated with asthma in multiple locations. However, only a few of these considered risk factors by community $(5,6)$. Although the inclusion of several communities in an analysis aids in examining determinants of asthma in general, assessment of exposures at the local level is important for both the etiological understanding of asthma and the application of interventions.

Hessel et al (5) and Duhme et al (6) have shown that environmental factors are not consistently associated with asthma across different locations within the same study. Although our study supports this, some of the significant associations between asthma and environmental factors differed between our study and that of Hessel et al (5) and Duhme et al (6). These inconsistencies could be due to differences in methods or variations in settings.
Hessel et al (5) conducted a cross-sectional study followed by a case-control study in two Canadian communities from a similar region. A stratified, multivariate analysis showed differences in the association between various risk factors and asthma between communities. Although Hessel et al (5) focused on a sample of the population, we were able to approach all eligible school children within each study community, and experienced excellent participation rates from both communities. In addition, our study focused on a narrower age range (six to 13 years) compared with the study by Hessel et al (5) (five to 19 years), which could reduce potential confounding factors such as a personal smoking history with older children. In a cross-sectional study by Duhme et al (6) in Germany, associations with asthma were studied in two communities with differences in the associations between communities being seen for five- to eight-year-old children; however, the two communities being compared were from different regions (one was a coastal city and the other was an inland city).

Although the communities we studied were both in the southern region of Saskatchewan and had many similarities in size and industry, some differences may have influenced the findings. The area surrounding Estevan is the site of strip mining for coal and coal-fired power plants. Air quality measurements were available in Estevan; however, they were not available in Swift Current 
and, therefore, could not be used in the present study. Estevan averages more annual rainfall than Swift Current $(333.1 \mathrm{~mm}$ versus $265.2 \mathrm{~mm}$, respectively) (31), and has a lower unemployment rate than Swift Current (2.2\% versus 3.8\%), although both communities are below the Canadian unemployment rate (32).

One limitation of our study is that no objective measures of exposure were collected. However, our definitions of exposures (eg, previous ETS exposure and current ETS exposure from maternal and paternal sources) are similar to those used in other epidemiological studies of risk factors for asthma, and our findings, for the most part, are consistent with those of other studies.

\section{CONCLUSIONS}

We found that the prevalence of exposures and the associations between asthma and some indoor environmental exposures differed between two communities within the southern region of Saskatchewan. We have provided further evidence that exposure to ETS in children is important when considering asthma. We have also shown that other indoor environmental characteristics, such as home mould or dampness, are important but may be most significant at a local level. Finally, we have shown that although

\section{REFERENCES}

1. Worldwide variations in the prevalence of asthma symptoms: The International Study of Asthma and Allergies in Childhood (ISAAC). Eur Respir J 1998;12:315-35.

2. Pearce N, Weiland S, Keil U, et al. Self-reported prevalence of asthma symptoms in children in Australia, England, Germany and New Zealand: An international comparison using the ISAAC protocol. Eur Respir J 1993;6:1455-61.

3. Health Canada. Childhood Asthma in Sentinal Units: Report of the Student Lung Health Study Results 1995-1996. Ottawa: Respiratory Disease Division, Laboratory Centre for Disease Control, 1998.

4. Dales RE, Raizenne M, el-Saadany S, Brook J, Burnett R. Prevalence of childhood asthma across Canada. Int J Epidemiol 1994;23:775-81.

5. Hessel PA, Klaver J, Michaelchuk D, McGhan S, Carson MM, Melvin D. The epidemiology of childhood asthma in Red Deer and Medicine Hat, Alberta. Can Respir J 2001;8:139-46.

6. Duhme H, Weiland SK, Rudolph P, Wienke A, Kramer A, Keil U. Asthma and allergies among children in West and East Germany: A comparison between Munster and Greifswald using the ISAAC phase I protocol. International Study of Asthma and Allergies in Childhood. Eur Respir J 1998;11:840-7.

7. Spengler J, Neas L, Nakai S, et al. Respiratory symptoms and housing characteristics. Indoor Air 1994;4:72-82.

8. Dekker C, Dales R, Bartlett S, Brunekreef B, Zwanenburg H. Childhood asthma and the indoor environment. Chest 1991;100:922-6.

9. Brunekreef B, Dockery DW, Speizer FE, Ware JH, Spengler JD, Ferris BG. Home dampness and respiratory morbidity in children. Am Rev Respir Dis 1989;140:1363-7.

10. Rennie DC, Lawson JA, Cockcroft DW, Senthilselvan A, McDuffie HH. Differences in respiratory symptoms and pulmonary function in children in 2 Saskatchewan communities. Ann Allergy Asthma Immunol 2004;92:52-9.

11. Ferris B Jr. Epidemiology Standardization Project. Am Rev Respir Dis $1978 ; 118: 36-47$.

12. Hosmer D, Lemeshow S. Applied Logistic Regression. New York: John Wiley \& Sons, 1989.

13. Celedon JC, Soto-Quiros ME, Silverman EK, Hanson L, Weiss ST. Risk factors for childhood asthma in Costa Rica. Chest 2001;120:785-90

14. Ehrlich RI, Du Toit D, Jordaan E, et al. Risk factors for childhood asthma and wheezing. Importance of maternal and household smoking. Am J Respir Crit Care Med 1996;154:681-8.

15. Sarafino EP. Connections among parent and child atopic illnesses. Pediatr Allergy Immunol 2000;11:80-6.

16. Matsuoka S, Nakagawa R, Nakayama H, Yamashita K, Kuroda Y. Prevalence of specific allergic diseases in school children as related to parental atopy. Pediatr Int 1999;41:46-51.

17. von Mutius E, Nicolai T. Familial aggregation of asthma in a South Bavarian population. Am J Respir Crit Care Med 1996;153:1266-72. risk factors for asthma are generally similar in boys and girls, there are potential differences. Future considerations in studies of regional variation in asthma should include monitoring of the ambient outdoor environment, and objective measures of the indoor environmental factors within communities. Additionally, the differential effects of various exposures on boys and girls should be investigated. Despite some limitations, our study was population-based, with both communities having excellent participation rates and using identical questionnaires and design, including the dates of data collection. Results of the present study provide evidence that development of asthma programs will need to consider characteristics specific to the respective communities.

ACKNOWLEDGEMENTS: The present research was funded by the Saskatchewan Lung Association. Dr Cockcroft is the Ferguson Professor of Respiratory Medicine (LAS). The authors acknowledge L Dwernychuk and N Franz for collecting the data, and L Hagel for entering and performing quality control checks on the data. The authors also thank the participating school boards, principals, teachers, parents and physicians in the community for their support of this project.

18. Jenkins MA, Hopper JL, Giles GG. Regressive logistic modeling of familial aggregation for asthma in 7,394 population-based nuclear families. Genet Epidemiol 1997;14:317-32.

19. Litonjua AA, Carey VJ, Burge HA, Weiss ST, Gold DR. Parental history and the risk for childhood asthma. Does mother confer more risk than father? Am J Respir Crit Care Med 1998;158:176-81.

20. Cook DG, Strachan DP. Health effects of passive smoking-10: Summary of effects of parental smoking on the respiratory health of children and implications for research. Thorax 1999;54:357-66.

21. Strachan DP, Cook DG. Health effects of passive smoking. 6 . Parental smoking and childhood asthma: Longitudinal and case-control studies. Thorax 1998;53:204-12.

22. Agabiti N, Mallone S, Forastiere F, et al. The impact of parental smoking on asthma and wheezing. SIDRIA Collaborative Group. Studi Italiani sui Disturbi Respiratori nell'Infanzia e l'Ambiente. Epidemiology 1999;10:692-8.

23. Shaw R, Woodman K, Crane J, Moyes C, Kennedy J, Pearce N. Risk factors for asthma symptoms in Kawerau children. N Z Med J 1994;107:387-91.

24. Cunningham J, O'Connor G, Dockery D, Speizer F. Environmental tobacco smoke, wheezing, and asthma in children in 24 communities. Am J Respir Crit Care Med 1996;153:218-24.

25. Forastiere F, Corbo G, Michelozzi P, et al. Effects of environment and passive smoking on the respiratory health of children. Int J Epidemiol 1992;21:66-73.

26. Dales RE, Zwanenburg H, Burnett R, Franklin CA. Respiratory health effects of home dampness and molds among Canadian children. Am J Epidemiol 1991;134:196-203.

27. Bornehag CG, Blomquist G, Gyntelberg F, et al. Dampness in buildings and health. Nordic interdisciplinary review of the scientific evidence on associations between exposure to "dampness" in buildings and health effects (NORDDAMP). Indoor Air 2001;11:72-86.

28. Li DW, Kendrick B. Indoor aeromycota in relation to residential characteristics and allergic symptoms. Mycopathologia 1995;131:149-57.

29. Kuwahara Y, Kondoh J, Tatara K, et al. Involvement of urban living environments in atopy and enhanced eosinophil activity: Potential risk factors of airway allergic symptoms. Allergy 2001;56:224-30.

30. Riedler J, Braun-Fahrlander C, Eder W, et al; ALEX Study Team. Exposure to farming in early life and development of asthma and allergy: A cross-sectional survey. Lancet 2001;358:1129-33.

31. Environment Canada. Canadian climate normals or averages 1971-2000. <www.climate.weatheroffice.ec.gc.ca/climate_normals/> (Version current at August 15, 2005).

32. Statistics Canada. Census Canada 2001 Community Profiles. $<$ http://www12.statcan.ca/english/profil01/PlaceSearchForm1.cfm> (Version current at August 15, 2005). 


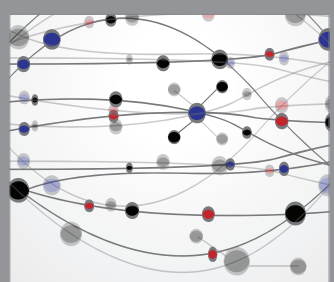

The Scientific World Journal
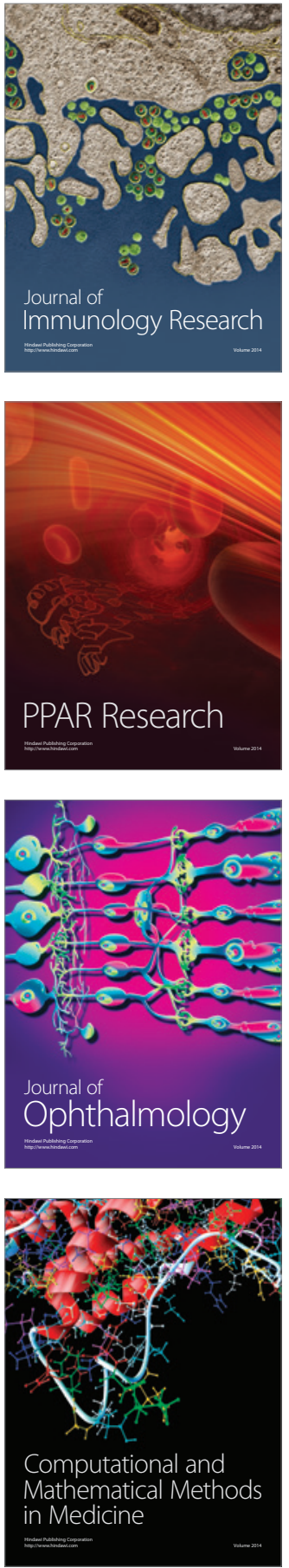

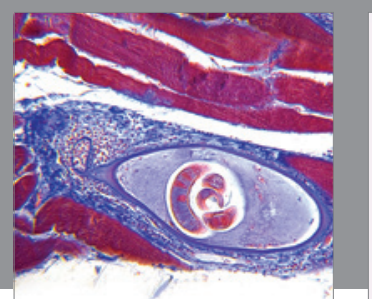

Gastroenterology Research and Practice

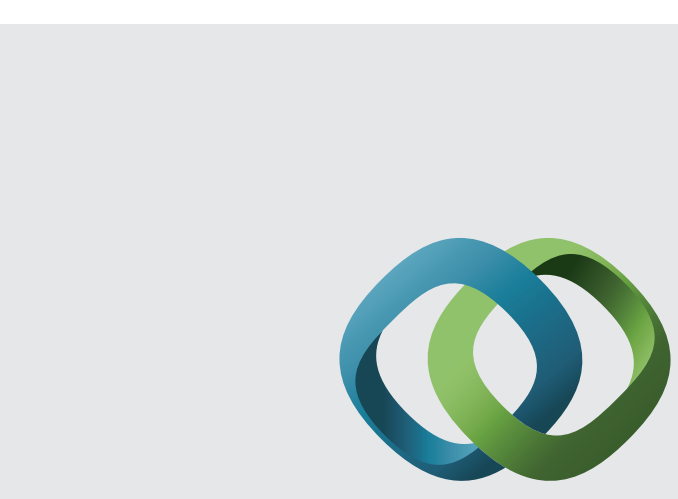

\section{Hindawi}

Submit your manuscripts at

http://www.hindawi.com
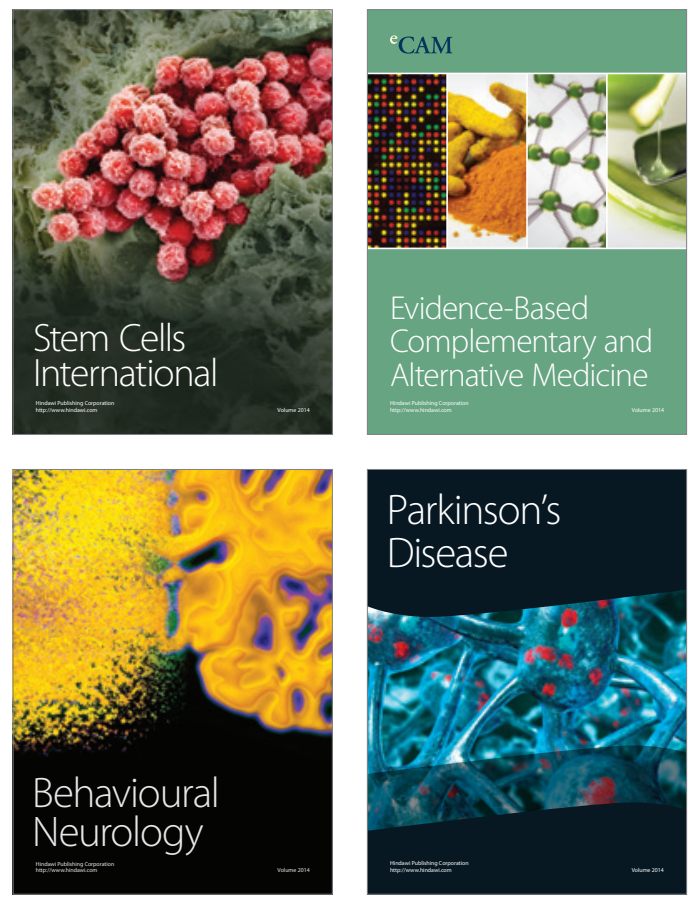
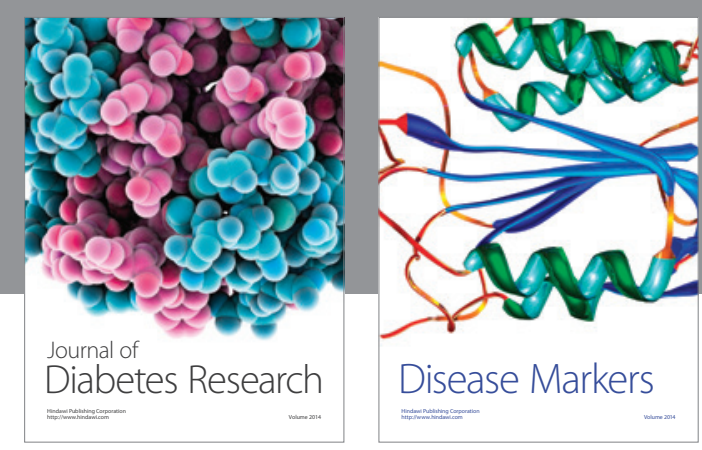

Disease Markers
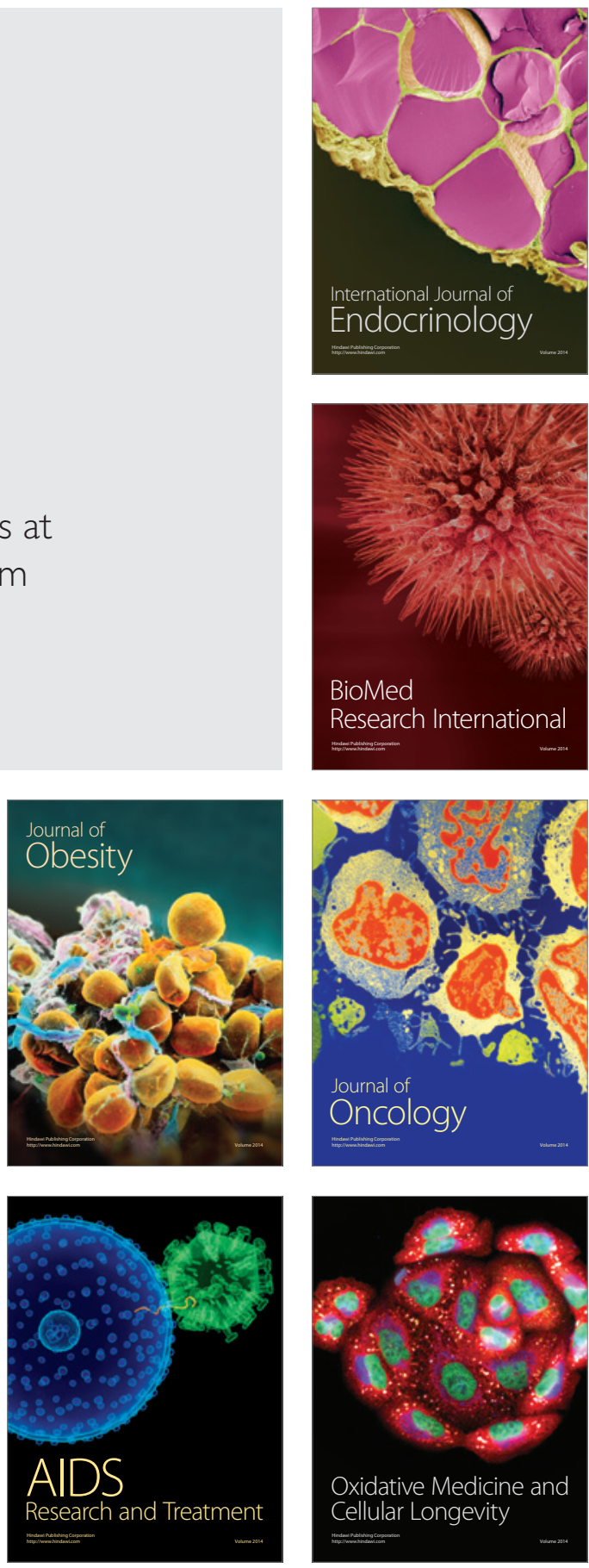